\title{
Numerical Analysis of Soil Improvement for a Foundation of a Factory Using Stone Columns Made of Different Types of Coarse-grained Materials
}

\author{
Jakub Stacho ${ }^{1 *}$, Monika Sulovska $^{1}$ \\ 1 Department of Geotechnics, \\ Faculty of Civil Engineering, \\ Slovak University of Technology in Bratislava, \\ Radlinskeho 11, 81005 Bratislava, Slovakia \\ * Corresponding author, e-mail: jakubstacho22@gmail.com
}

Received: 13 January 2019, Accepted: 14 June 2019, Published online: 11 July 2019

\begin{abstract}
Stone columns made of coarse-grained materials and crushed stone are one of the most-used technologies for soil improvement all over the world. Stone columns improve the strength and deformation properties of subsoil and reduce the time required for the consolidation of fine-grained soils. The impact of the improvement depends on the properties of the original subsoil as well as the properties of the coarse-grained materials used for the stone columns. The article deals with the effects of the properties of coarsegrained materials for stone columns on the settlement and consolidation times of improved subsoil for the foundation of a factory. Numerical modeling as a 2D task was performed using Plaxis geotechnical software. The numerical analysis included two methods of modeling stone columns in a plane strain model, i.e., one method often used by practical engineers in the region of Slovakia, and one modified method, which allowed for a more accurate determination of the final settlement and consolidation time. The method modeled stone columns as continuous walls, and the compaction of the soil between the stone columns was taken into account. The results showed that the type of coarse-grained material can significantly affect the final settlement and time of consolidation. Stone columns made of quarry stone were suitable in the given geological conditions regardless of the design of the mesh, while stone columns made of pebble gravel were suitable only with a mesh of $1.5 \times 1.5 \mathrm{~m}$.
\end{abstract}

\section{Keywords}

soil improvement, stone columns, foundation design

\section{Introduction}

Stone columns are one of the most-often-used technologies for soil improvement. They have been used since the 1950s. Stone columns are vertical columns made of coarsegrained soil or crushed stone placed into the soil below a structure that requires improvement of the original subsoil. The technology can improve the properties of the original subsoil, increase its drainage, and reduce the time required for its consolidation. Computational methods are constantly being developed and modified to obtain economic and effective designs. The technology has already been investigated and analyzed by many authors. Hughes and Withers [1] were the first who analyzed the complex behavior of stone columns, e.g., load transfer mechanisms. The main formula for determining the resistance of a stone column, taking into account friction failure, was created by
Wong [2]. Watts et al. [3] determined that embedded stone columns are especially suitable for the reduction of settlement and that a friction stone column increases resistance.

Priebe [4] was the first to introduce a general shear-failure pattern and the equivalent width of a foundation to predict the resistance of a group of stone columns. Hu et al. [5] presented the results of laboratory tests that showed that the failure of a group of stone columns results in a conical shape. Numerical analyses that confirmed these results were presented by, e.g., [6, 7]. Many methods have been proposed to convert the task to an equivalent plane-strain model for the purpose of 2D numerical modeling [8-10]. Castro and Sagaseta [11] presented different approaches and methods for the numerical modeling of stone columns, i.e., homogenization of the improved subsoil, transformation 
of stone columns into continuous walls, transformation of stone columns into a ring, unit cell (elementary cell), and 3D numerical modeling. The homogenization of the improved subsoil is based on a determination of the equivalent properties in the zone of improvement, e.g., $[12,13]$. The effect of the stone columns is distributed to the original soil. The transformation of stone columns to stone walls is based on the walls having the same volume as the individual stone columns [14]. Because the area of a stone wall is greater than the area of stone columns, this method requires a determination of the equivalent (reduced) coefficient of filtration in the area of the improvement [15]. The most optimal numerical model is a full 3D model. Numerical modeling of stone columns using 3D model have been analyzed by, e.g., $[16,17]$.

The installation process of stone columns results in the compaction of the surrounding soil. This effect is not often taken into account in numerical models. The numerical modeling of a single-stone column installation has been analyzed by, e.g., Weber [16], Stacho [18]. Partial results from these studies have been applied in the models presented.

The aim of the study presented in this article is an analysis of the effect of coarse-grained materials used for stone columns on the final settlement and consolidation time of the improved subsoil. The effect of the improvement mostly depends on the properties of the original subsoil as well as the properties of the coarse-grained material used for the stone columns. Three different types of coarse-grained materials were taken into account for the improvement of the subsoil for the foundation of a factory. The properties of the coarse-grained materials were determined using in-situ and laboratory tests. Two different methods of modeling stone columns in a plane strain model were used.

\section{Installation of the stone columns tested and determination of their properties}

The area tested with the stone columns is shown in Fig. 1. The stone columns were divided according to the technology into vibro-replacement and vibro-compaction [19]. There are two principles for the construction of stone columns using the vibro-replacement technique, i.e., the top feed process and the bottom feed process. The stone columns tested were installed using the vibro-replacement technique with the bottom feed process. The area tested included 9 stone columns, i.e., 3 made of pebble gravel, 3 made of crushed pebble gravel, and 3 made of quarry stone [20].

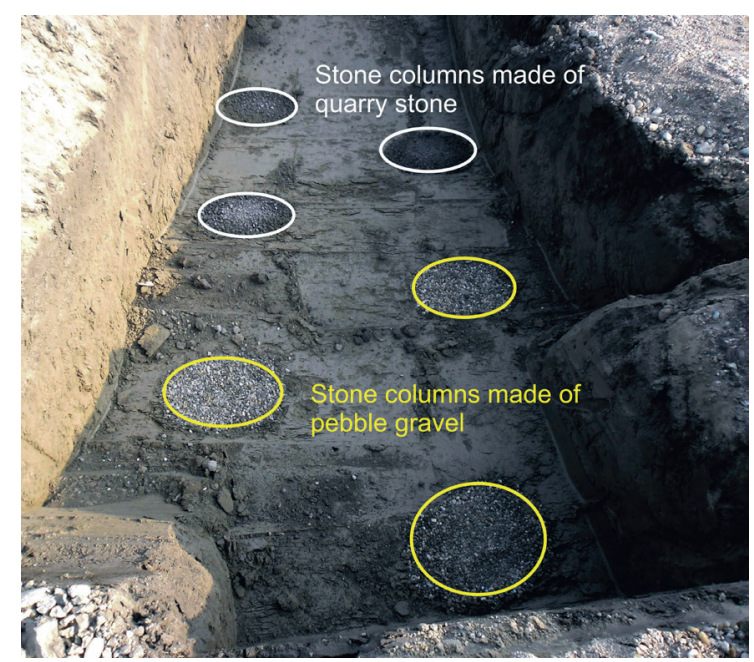

Fig. 1 Stone columns in the area tested

The original subsoil consists of very soft clay with a high plasticity (a firm consistency) to a depth of $5 \mathrm{~m}$ below the surface (Layer 1) and well-graded gravel below it (Layer 2). The properties of the original subsoil were determined using standard laboratory tests [20]. A bearing (leveling) layer of compacted gravel of a thickness of $1 \mathrm{~m}$ was designed for the top of the surface. The layer transfers the load directly to the stone columns. The pressurized ground water level (GWL) was measured at the boundary between the fine-grained and coarse-grained soil. All the input properties of these layers are shown in Table 2. The properties of the coarse-grained material of the stone columns were determined using in-situ and laboratory tests. The bulk density of the material of the stone column was determined using pit tests on the existing stone columns tested. The minimal and maximal density was determined in the laboratory, which allowed for determining the density index of the stone columns [21]. A summary of the results is shown in Table 1. The grain size distribution curves of all the materials are presented in Fig. 2, and the grain sizes and shapes of the coarse-grained materials taken from the stone columns tested are also shown in Fig. 3.

Table 1 Bulk density and density indexes of the coarse-grained materials tested

\begin{tabular}{|c|c|c|c|c|c|}
\hline \multirow{3}{*}{ Material } & \multirow{3}{*}{$\rho_{\min }$} & \multirow{3}{*}{$\rho_{\max }$} & \multicolumn{2}{|c|}{$\begin{array}{l}\text { Depth below the } \\
\text { surface }\end{array}$} & \multirow{3}{*}{$I_{\mathrm{d}}$} \\
\hline & & & $\pm 0.0 \mathrm{~m}$ & $-0.9 \mathrm{~m}$ & \\
\hline & & & $\rho_{\mathrm{d}, \text { average }}$ & $\rho_{\mathrm{d} \text {,average }}$ & \\
\hline Quarry stone & 1277.9 & 1909.45 & 1943.9 & 1606.7 & $0.62-0.90$ \\
\hline $\begin{array}{l}\text { Crushed } \\
\text { pebble gavel }\end{array}$ & 1435.5 & 1966.87 & 1532.4 & 1900.8 & $0.23-0.91$ \\
\hline Pebble gravel & 1512.8 & 1884.81 & 1783.1 & 1718.8 & $0.61-0.77$ \\
\hline
\end{tabular}




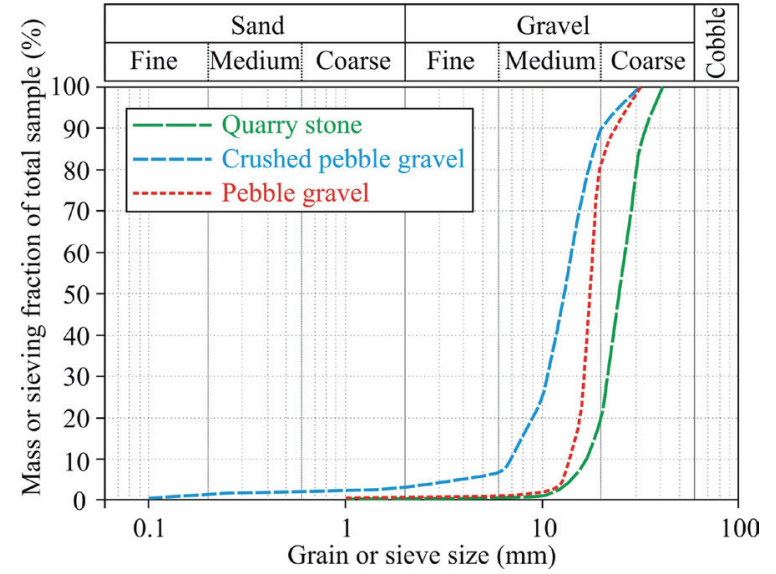

Fig. 2 Grain size distribution curves of the coarse-grained materials tested

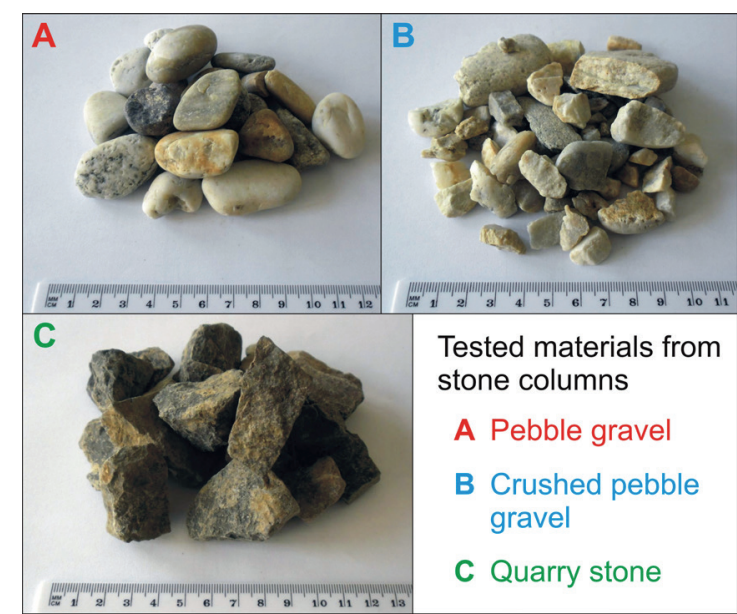

Fig. 3 Sizes and shapes of the coarse-grained materials tested

The shear strength properties were determined using a large dimensional direct shear test apparatus. The box of the apparatus has dimensions of $300 \times 300 \mathrm{~mm}$ and a height of $200 \mathrm{~mm}$. The tests were executed on the coarse-grained material taken from the stone columns tested. Shear stresses were measured for three normal stresses of 50, 100 and $150 \mathrm{kN} \cdot \mathrm{m}^{-2}$. The results showed that the angle of shear strength is about $50^{\circ}$ for the pebble gravel and $52^{\circ}$ for the crushed pebble gravel. The shear strength of the quarry stone was given by the angle of shear strength at a value of about $48^{\circ}$ and an initial shear strength of $57 \mathrm{kN} . \mathrm{m}^{-2}$, which was caused by the wedging of the grains. The failure envelopes, which were determined using the large dimensional direct shear tests, are shown in Fig. 4.

The deformation modulus and density index were determined using a Frowag MDP-50 light dynamic penetration test tool. The soil properties were determined using the correlation formulas according to Turcek et al. [20]. The density index was determined using Eq. (1) and the deformation modulus according to Eq. (2):

$$
\begin{aligned}
& I_{D}=a \cdot q_{d y n}{ }^{b}, \\
& E_{d e f}=n \cdot q_{d y n}{ }^{m},
\end{aligned}
$$

where $q_{d v n}$ measured the dynamic penetration resistance, and the coefficients $a, b, n$ and $m$ were determined according to the type of soil $(a=0.13 ; b=0.16 ; n=8.8$ and $m=$ 0.83 for the stone columns) [20].

The soil properties of all the original soils for the numerical modeling are summarized in Table 2. The deformation properties which were not determined using the tests, e.g., $E_{50}, E_{\text {ur }}$ and $m$, were determined according to previous experience [21]. The numerical models based on the homogenization of the improved subsoil required the determination of the homogenized soil properties according to the equations presented by, e.g., [13]. The properties used in the numerical analysis are given in Table 3.

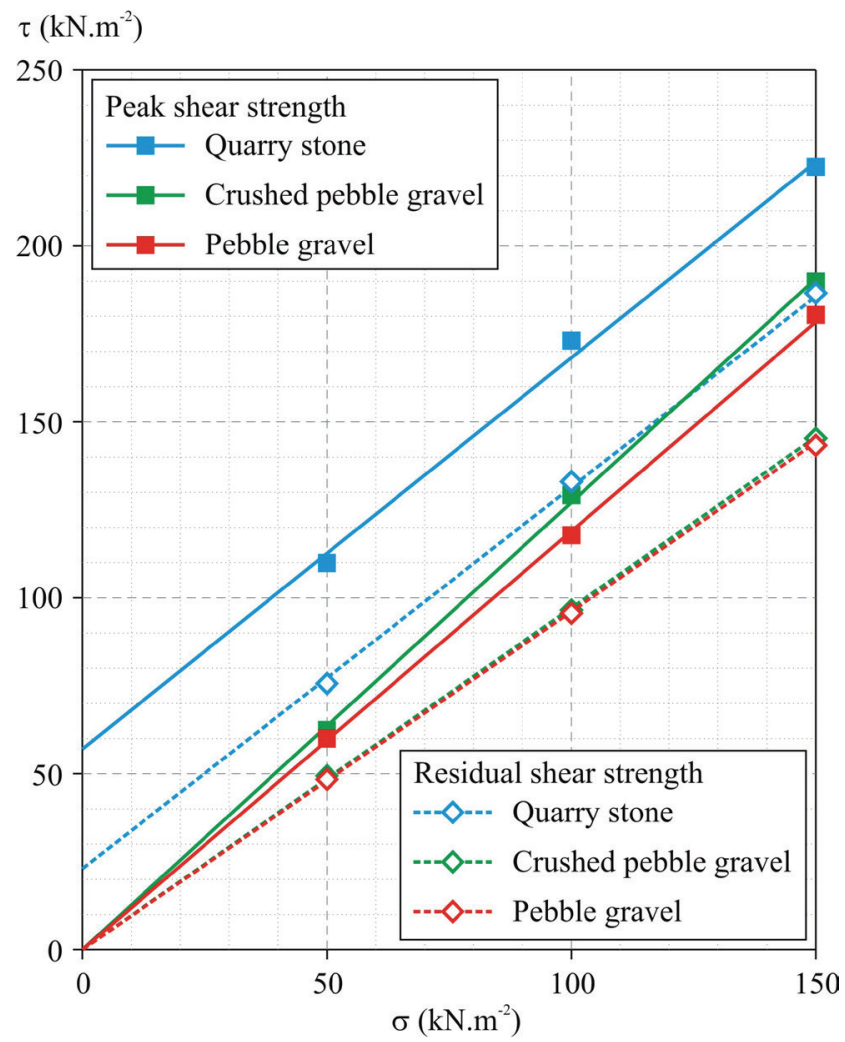

\begin{tabular}{|l|l|l|}
\hline Quarry stone & $\varphi^{\prime}=48.0^{\circ}$ & $\varphi_{\mathrm{r}}=47.3^{\circ}$ \\
$\mathrm{I}_{\mathrm{D}}=0.70$ - dense & $\tau_{0}{ }^{\prime}=57.0 \mathrm{kPa}$ & $\tau_{0, \mathrm{r}}=23.0 \mathrm{kPa}$ \\
\hline \hline Crushed pebble gravel & $\varphi^{\prime}=51.8^{\circ}$ & $\varphi_{\mathrm{r}}=44.0^{\circ}$ \\
$\mathrm{I}_{\mathrm{D}}=0.54$ - middle density & $\tau_{0}^{\prime}=0.0 \mathrm{kPa}$ & $\tau_{0, \mathrm{r}}=0.0 \mathrm{kPa}$ \\
\hline \hline Pebble gravel & $\varphi^{\prime}=49.9^{\circ}$ & $\varphi_{\mathrm{r}}=43.8^{\circ}$ \\
$\mathrm{I}_{\mathrm{D}}=0.49$ - middle density & $\tau_{0}{ }^{\prime}=0.0 \mathrm{kPa}$ & $\tau_{0, \mathrm{r}}=0.0 \mathrm{kPa}$ \\
\hline
\end{tabular}

Fig. 4 Failure envelopes of the coarse-grained materials tested, which were determined using the large dimensional direct shear test 
Table 2 Input soil properties of the original soil and coarse-grained materials of the stone columns

\begin{tabular}{|c|c|c|c|c|c|c|c|}
\hline \multirow{2}{*}{\multicolumn{2}{|c|}{ Parameter / Unit }} & \multicolumn{6}{|c|}{ Material } \\
\hline & & \multirow{2}{*}{$\frac{\text { Layer } 1}{19}$} & \multirow{2}{*}{$\frac{\text { Layer } 2}{21}$} & \multirow{2}{*}{$\frac{\text { Bearing layer }}{21}$} & \multirow{2}{*}{$\frac{\text { Quarry Stone }}{16.81}$} & \multirow{2}{*}{$\frac{\text { Crushed pebble gravel }}{17.36}$} & \multirow{2}{*}{$\frac{\text { Pebble grave }}{18}$} \\
\hline$\gamma$ & $\mathrm{kN} \cdot \mathrm{m}^{-3}$ & & & & & & \\
\hline$\gamma_{\text {sat }}$ & $\mathrm{kN} \cdot \mathrm{m}^{-3}$ & 20.45 & 21.55 & 21.55 & 19.25 & 19.55 & 19.9 \\
\hline$E_{50}=E_{\text {oed }}$ & $\mathrm{MN} \cdot \mathrm{m}^{-2}$ & 5.17 & 101 & 108 & 82.5 & 65.8 & 45.3 \\
\hline$E_{\mathrm{ur}}$ & $\mathrm{MN} \cdot \mathrm{m}^{-2}$ & 25.85 & 303 & 324 & 247.5 & 197.4 & 135.9 \\
\hline$m$ & - & 0.85 & 0.5 & 0.5 & 0.5 & 0.5 & 0.5 \\
\hline$\varphi^{\prime}$ & $\circ$ & 26.6 & 36.1 & 36.1 & 48 & 51.8 & 49.9 \\
\hline$\psi^{\prime}$ & $\circ$ & 0 & 6.1 & 6.1 & 18 & 21.8 & 19.9 \\
\hline$c^{\prime}$ & $\mathrm{kN} \cdot \mathrm{m}^{-2}$ & 10.8 & 1 & 1 & 57 & 1 & 1 \\
\hline$k_{\mathrm{x}}=k_{\mathrm{y}}$ & m.day $^{-1}$ & $0.01037 .10-3$ & 86.4 & 864 & 864 & 864 & 864 \\
\hline$K_{0}$ & - & 0.5522 & 0.4108 & 0.4108 & 0.3 & 0.3 & 0.3 \\
\hline
\end{tabular}

Table 3 Input soil properties of the homogenized subsoil and soil between the stone columns

\begin{tabular}{|c|c|c|c|c|c|c|c|c|c|c|}
\hline \multicolumn{2}{|c|}{ Material } & \multicolumn{3}{|c|}{ Quarry stone } & \multicolumn{3}{|c|}{ Crushed pebble gravel } & \multicolumn{3}{|c|}{ Pebble gravel } \\
\hline Mesh & $\mathrm{m}$ & $1.5 \times 1.5$ & $1.8 \times 1.8$ & $2 \times 2$ & $1.5 \times 1.5$ & $1.8 \times 1.8$ & $2 \times 2$ & $1.5 \times 1.5$ & $1.8 \times 1.8$ & $2 \times 2$ \\
\hline$\gamma$ & $\mathrm{kN} \cdot \mathrm{m}^{-3}$ & 18.44 & 18.61 & 18.69 & 18.58 & 18.71 & 18.77 & 18.75 & 18.82 & 18.86 \\
\hline$\gamma_{\text {sat }}$ & $\mathrm{kN} \cdot \mathrm{m}^{-3}$ & 20.14 & 20.24 & 20.28 & 20.22 & 20.29 & 20.32 & 20.31 & 20.35 & 20.37 \\
\hline$E_{50}=E_{\text {oed }}$ & MN.m ${ }^{-2}$ & 23.5 & 17.35 & 14.55 & 19.25 & 14.39 & 12.19 & 14.03 & 10.77 & 9.289 \\
\hline$E_{\mathrm{ur}}$ & MN.m ${ }^{-2}$ & 75.51 & 57.57 & 49.41 & 62.76 & 48.72 & 42.33 & 47.11 & 37.85 & 33.64 \\
\hline$\varphi^{\prime}$ & $\circ$ & 32.05 & 30.38 & 29.63 & 33.01 & 31.05 & 30.16 & 32.53 & 30.72 & 29.89 \\
\hline$c^{\prime}$ & $\mathrm{kN} \cdot \mathrm{m}^{-2}$ & 22.56 & 18.96 & 17.33 & 8.05 & 8.89 & 9.27 & 8.05 & 8.89 & 9.27 \\
\hline$k_{\mathrm{x}}=k_{\mathrm{y}}$ & m.day ${ }^{-1}$ & $1.37 .10-6$ & $1.31 .10-6$ & $1.28 .10-6$ & $1.37 .10-6$ & $1.31 .10-6$ & $1.28 .10-6$ & $1.37 .10-6$ & $1.31 .10-6$ & $1.28 .10-6$ \\
\hline
\end{tabular}

The coefficients of filtration, which take into account the conversion of a $3 \mathrm{D}$ task to a $2 \mathrm{D}$ task, were determined using the Eq. (3):

$$
k_{h p}=\frac{2 B^{2}}{3 R^{2}} \frac{k_{h a}}{\ln \frac{n_{a}}{s_{a}}-\frac{3}{4}+\frac{k_{h a}}{k_{s a}} \ln s_{a}},
$$

where $B, R, n_{a}$ and $s_{a}$ are dimensions that depend on the geometry of the stone columns, and $k_{h a}$ and $k_{s a}$ are the coefficients of filtration [15].

In cases when the compaction of the soil between stone columns is taken into account, the most significant change occurs to the deformation modules, and there is a change in the coefficient of the lateral earth pressure in the zone of compaction. The averaged values of the changed soil properties of the compacted original soil are presented in Table 4. These properties were determined from the axisymmetrical numerical models of single stone columns that were focused on their installation process. In the initial phase of the model, the cluster of stone columns has a radius of $0.01 \mathrm{~m}$, and their stability is controlled by a zero prescribed displacement. The radius is increased to $0.3 \mathrm{~m}$ in the second phase, so the soil is laterally displaced and compacted.
Table 4 Layer 1 soil properties which were changed by the installation of the stone columns

\begin{tabular}{lcccc}
\hline Mesh & $\mathrm{m}$ & $1.5 \times 1.5$ & $1.8 \times 1.8$ & $2 \times 2$ \\
\hline$K$ & - & 1.697 & 1.306 & 1.135 \\
$n$-time of $E_{\text {oed }}$ & - & 1.65 & 1.47 & 1.36 \\
\hline
\end{tabular}

The properties of the stone columns are subsequently activated. The coefficient of the lateral earth pressure is computed as a ratio of the effective horizontal and vertical geostatic stresses. The whole process is described in detail by [18], according to the approach first presented by Weber [16].

\section{Creating a numerical model}

Numerical models were created using Plaxis software as the plane strain models. The soil properties were modeled using the Hardening soil material model. The advantages of this model were presented by, e.g., [22]. The coarse-grained soils were modeled as drained, and the fine-grained soil was modeled as undrained. The width of the factory is $60 \mathrm{~m}$. The total width of the improved area is $80 \mathrm{~m}$. The bearing gravel layer with a thickness of $1 \mathrm{~m}$ was designed for the top of the surface. The thickness of the fine-grained layer was $5 \mathrm{~m}$. 
The stone columns have a diameter of $600 \mathrm{~m}$ and a length of $5 \mathrm{~m}$ and are finished at the top of the coarse-grained bearing stratum. The loading of the most loaded part of the factory was defined with a uniform load at the top of the surface at a value of $80 \mathrm{kN} \cdot \mathrm{m}^{-2}$. The stone columns were modeled in three meshes (plan layouts): $1.5 \times 1.5 \mathrm{~m}, 1.8 \times 1.8 \mathrm{~m}$, and $2.0 \times 2.0 \mathrm{~m}$. The first model with stone columns designed in a square mesh of $1.5 \times 1.5 \mathrm{~m}$ is shown in Fig. 5. There were 54 stone columns in one row. The stone columns were transferred to a wall with a width of $0.19 \mathrm{~m}$. The second model was created for stone columns with mesh dimensions of $1.8 \times 1.8 \mathrm{~m}$. There, 45 stone columns were modeled in one row, and the width of the wall was $0.14 \mathrm{~m}$. The third model was a model with stone columns designed with a $2.0 \times 2.0 \mathrm{~m}$ mesh. There, 40 stone columns in one row were modeled, and the width of the wall was $0.14 \mathrm{~m}$. The following methods of modeling the stone columns were used:

- Model 1: Homogenization of the subsoil. The stone columns were not modeled; only the drains for consolidation were activated in place of the stone columns. The reduced coefficient of filtration was used;

- Model 2: The stone columns were transferred to the walls. The compaction of the soil between the stone columns was taken into account. The properties of the compacted original soil are listed in Table 4.

The first phase defined the initial stress state. The stone columns were activated in the second phase. The third phase included the activation of the upper gravel-bearing layer with a thickness of $1 \mathrm{~m}$. The loading was activated in the fourth phase. The construction phases were defined as consolidation phases with corresponding times. The last phase was defined as a consolidation phase that will finish when the excess pore pressures have decreased to less than 1 kN.m ${ }^{-2}$.

\section{Verification of the modeling methodology with a similar example using geotechnical monitoring}

The construction of the factory was planned for the following year. The analysis presented in this article is focused on the selection of the most effective soil improvement design using stone columns. In the first step, it was necessary to verify the methodology of our type of numerical modeling in similar conditions where the geotechnical monitoring included measurements of the settlement and consolidation. This study was presented in detail by the Stacho et al. [23]. The construction analyzed was a road embankment founded on a similar soft subsoil that was improved using stone columns made of pebble gravel. The deformation of the base of the embankment was measured using a horizontal inclinometer. The final settlements as well as the times required for consolidation were recorded. The stone columns were modeled using the two methods described above. The results of the analysis are shown in Fig. 6 .

They show that Model 1 estimated that longer times were required for consolidation in comparison to the results of the measurements. More optimal results were obtained using Model 2. The model estimated very similar times of consolidation with the measurements and also provided a smaller value of the settlement, which was closer to the settlement determined by the measurement.

\section{Results of study}

The results of the numerical analysis for soil improvement using stone columns in a square mesh with dimensions of $1.5 \times 1.5 \mathrm{~m}$ are presented in Fig. 7. Regarding the comparison of the different types of coarse-grained materials, the use of quarry stone led to a determination of the smallest amount of settlement and the shortest times required for consolidation regardless of the model used. The use

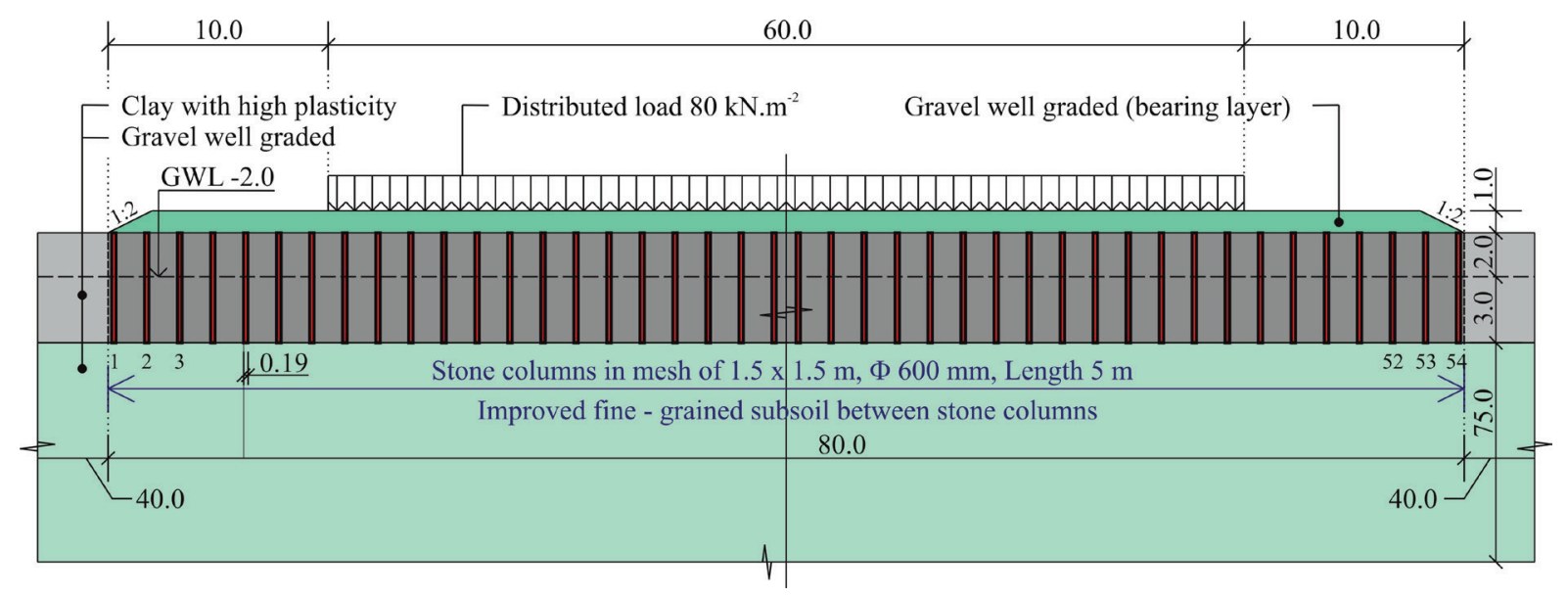

Fig. 5 Scheme of the numerical model with stone columns in a square mesh of $1.5 \times 1.5 \mathrm{~m}$ 


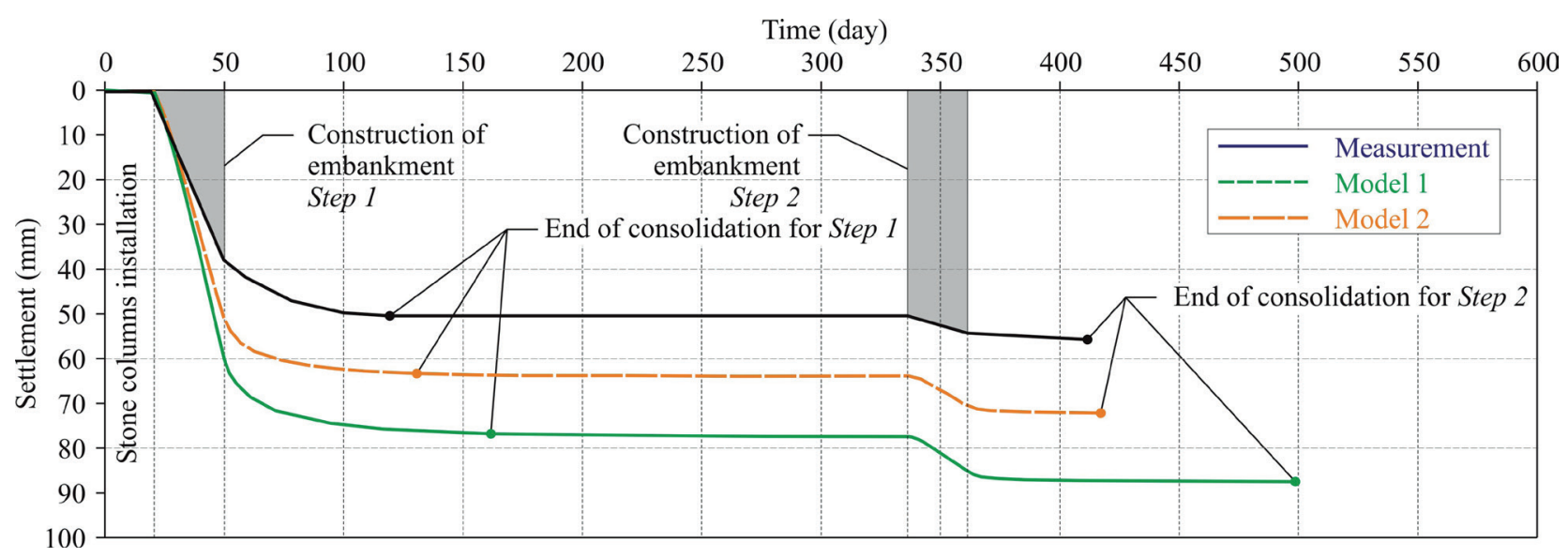

Fig. 6 Analysis of settlement of road embankment for verification of numerical modeling [23]

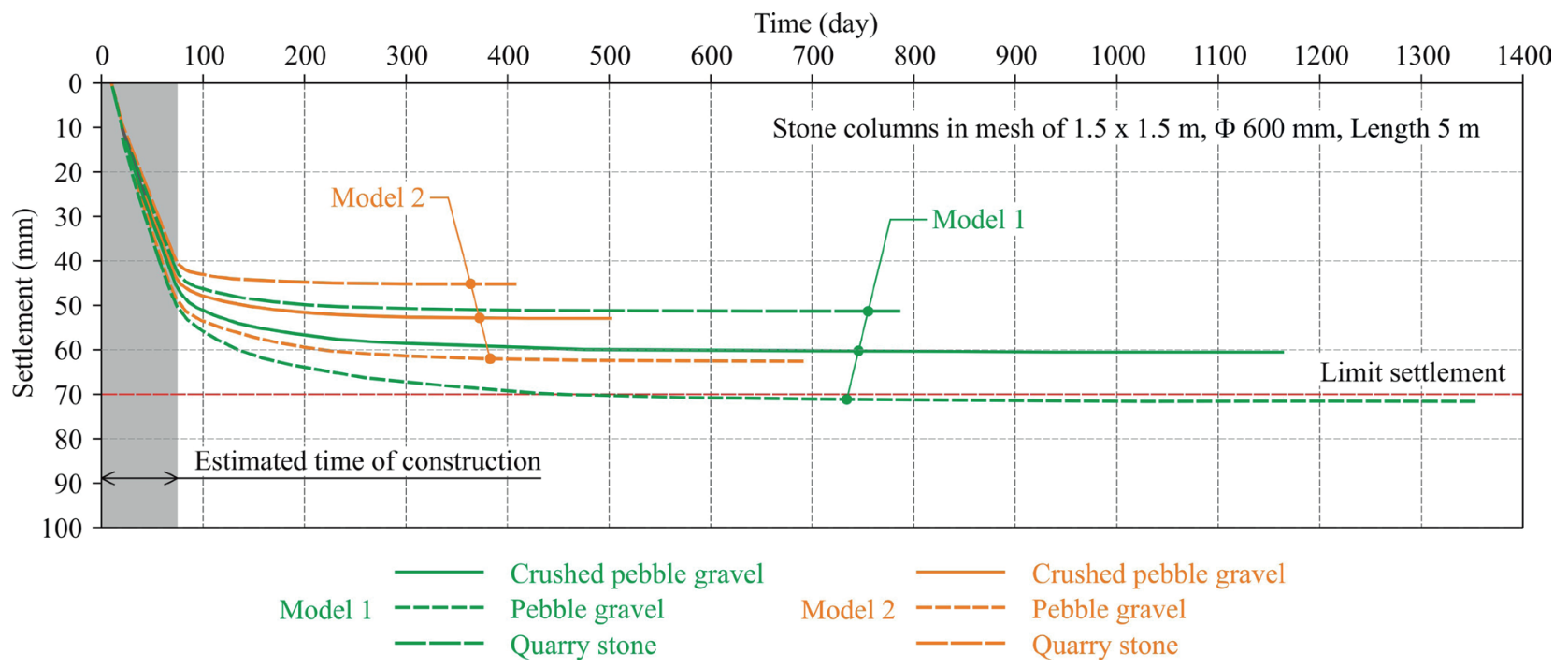

Fig. 7 Time - settlement curves for soil improvement using stone columns in the plan layout of $1.5 \times 1.5 \mathrm{~m}$

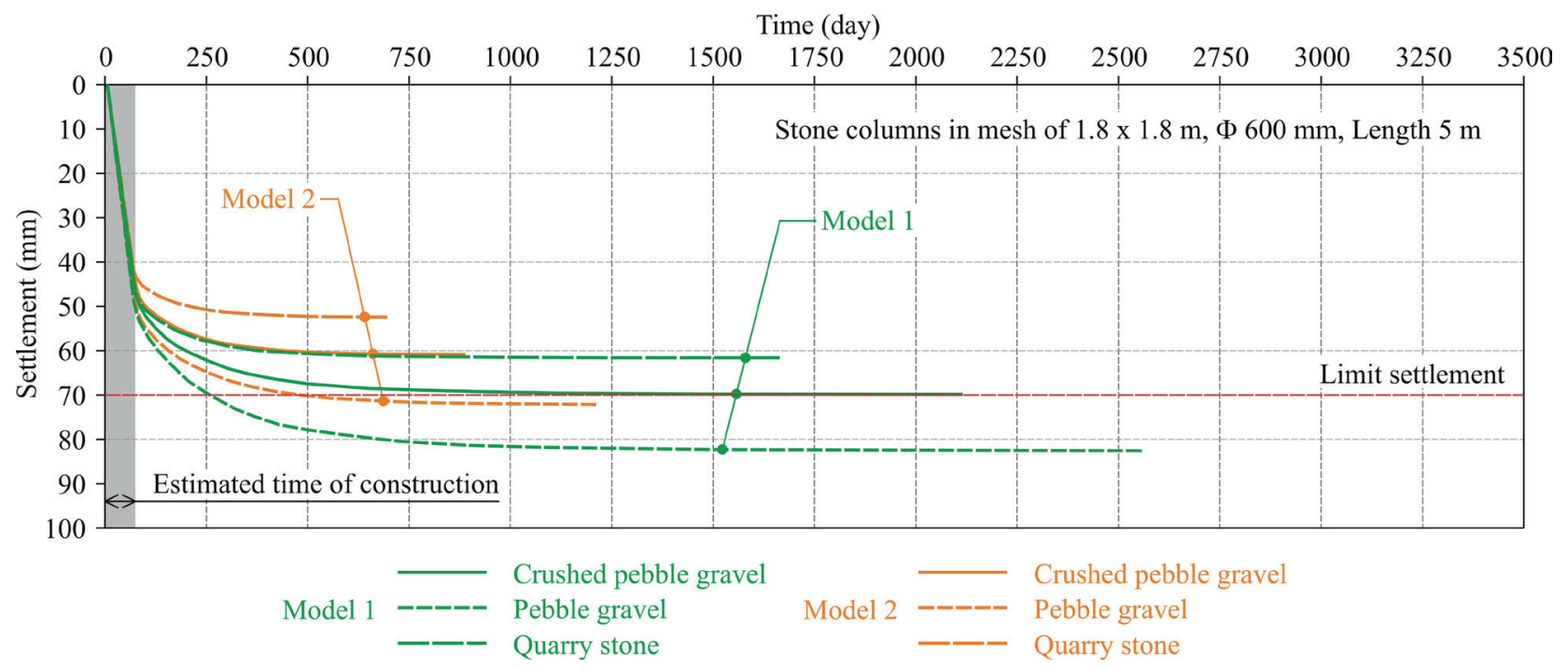

Fig. 8 Time - settlement curves for soil improvement using stone columns in the plan layout of $1.8 \times 1.8 \mathrm{~m}$ 


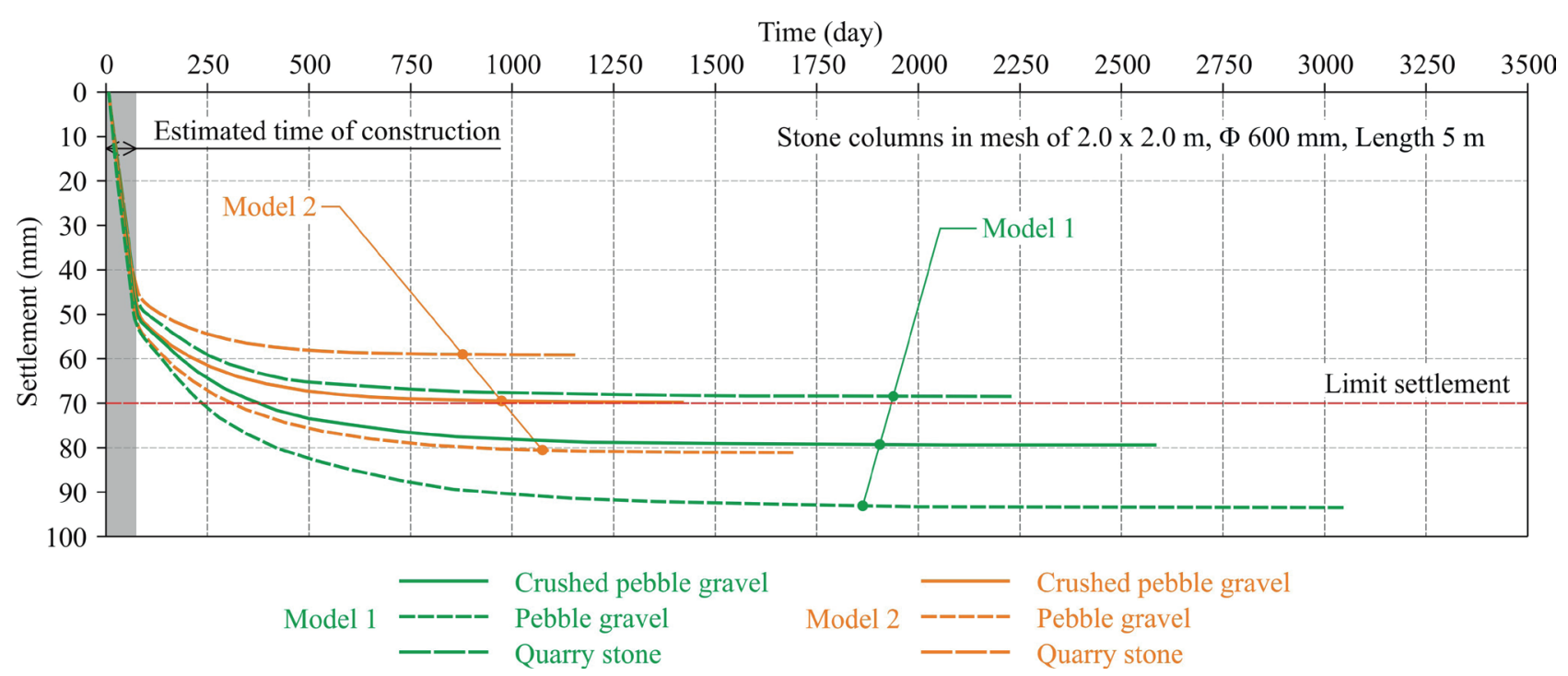

Fig. 9 Time - settlement curves for soil improvement using stone columns in the plan layout of $2.0 \times 2.0 \mathrm{~m}$

of pebble gravels led to the greatest deformations and the longest consolidation times in both models. The deformations computed using Model 1 were acceptable, but the times required for the consolidation were too high. The deformations determined when using Model 2 were in a range of 45 to $62 \mathrm{~mm}$. The estimated time required for consolidation was 406 days for the stone columns made of quarry stone, 501 days for the stone columns made of crushed pebble gravel, and 690 days for the stone columns made of pebble gravel.

The numerical model with stone columns in a square mesh section of $1.8 \times 1.8 \mathrm{~m}$ (Fig. 8 ) led to the determination of somewhat bigger final settlements. The increases in the settlements were about 10 to $15 \%$. The times required for full consolidation increased from about 1.8 up to 2.4 times in Model 1 and about 1.7 to 1.77 times in Model 2.

The results of the analysis of the numerical model with stone columns in a square mesh section of $2.0 \times 2.0 \mathrm{~m}$ are presented in Fig. 9. The settlements increased about $10 \mathrm{~mm}$ in comparison to the numerical model with stone columns in a mesh section of $1.8 \times 1.8 \mathrm{~m}$. The settlement at the end of the construction increased from about 57 to $70 \%$ in the case of Model 1 and about 65 to $77 \%$ in the case of Model 2.

The results of the analysis show that the smallest amount of settlement and the shortest times of consolidation are reached when the stone columns are made of quarry stone. The standard limit settlement was not exceeded in any plan layout of the stone columns. The biggest settlements and the longest times of consolidation were reached in the case of the stone columns made of pebble gravel. In the given geological conditions, the limit value of the settlement was reached only in the plan layout of $1.5 \times 1.5 \mathrm{~m}$. The stone columns made of crushed pebble gravel led to a determination of the approximately mean values of the settlement and consolidation times. The results of Model 2 were estimated as the most accurate, depending on the results of the analysis presented in Fig. 6.

\section{Conclusions}

The paper presents the results of the analysis of the improvement of the soft clayey subsoil which was improved using stone columns for the foundation of a factory. The aim of the analysis was to determine the differences between stone columns made of various types of coarse-grained materials. Three tested stone columns made of pebble gravel, 3 stone columns made of crushed pebble gravel, and 3 stone columns made of quarry stone were installed. The testing of the stone columns permitted the determination of the properties of stone columns made of different types of coarse-grained materials in the same geological conditions. The results of the large dimensional direct shear tests showed that the angle of shear strength of pebble gravel is about $50^{\circ}$ and that of the crushed pebble gravel is about $52^{\circ}$. The angle of shear strength of the quarry stone was about $48^{\circ}$, but the material also had a significant initial shear strength of about $57 \mathrm{kN} . \mathrm{m}^{-2}$. The numerical analysis included 2 types of stone column modeling using a plane strain model. The stone columns were analyzed in square meshes with dimensions of $1.5 \times 1.5 \mathrm{~m}, 1.8 \times 1.8 \mathrm{~m}$, and $2.0 \times 2.0 \mathrm{~m}$. The most optimal result achieved when modeling the stone columns was using Model 2, where 
the stone columns were transferred to a continuous wall of the same volume; the compaction of the soil between the stone columns was taken into account using a changed coefficient of the lateral earth pressure, and the coefficient of filtration was reduced (modified) from the 3D task to a 2D task. The suitability of the model was also declared by the results of a numerical model from other construction where geotechnical monitoring was available. The smallest amount of settlement and the shortest times required

\section{References}

[1] Hughes, J. M. O., Withers, N. J. "Reinforcing of soft cohesive soils with stone columns", Ground Engineering, 7(3), pp. 42-49, 1974. [online] Available at: https:/www.geplus.co.uk/technical-paper/ technical-paper-reinforcing-of-soft-cohesive-soils-with-stone-columns-01-05-1974/ [Accessed: 25 June 2019]

[2] Wong, H.-Y. "Vibroflotation - its effect on weak cohesive soils", Civil Engineering, 82, pp. 44-67, 1975.

[3] Watts, K. S., Johnson, D., Wood, L. A., Saadi, A. "An instrumented trial of vibro ground treatment supporting strip foundation in a variable fill", Géotechnique, 50(6), pp. 699-708, 2000.

https://doi.org/10.1680/geot.2000.50.6.699

[4] Priebe, H. J. "The design of vibro replacement", Ground Engineering, 28(10), pp. 31-37, 1995. [online] Available at: https://www.geplus. co.uk/technical-paper/technical-paper-the-design-of-vibro-replacement-01-12-1995/ [Accessed: 25 June 2019]

[5] Hu, W., Muir Wood, D., Stewart, W. "Ground improvement using stone column foundations: Result of model tests", In: International Conference on Ground Improvement Techniques, Macao, 1997, pp. $247-256$.

[6] Wehr, W. "Schottersäulen-Das verhalten von einzelnen säulen und säulengruppen (Stone columns - The behaviour of individual stone columns and stone column groups)", Geotechnik, 22(1), pp. 40-47, 1999. (in German)

[7] Muir-Wood, D., Hu, W., Nash, D. F. T. "Group effects in stone column foundations: model tests", Ground and Soil Improvement, 51(7), pp. 649-658, 2001.

https://doi.org/10.1680/gasi.31708.0020

[8] Hird, C. C., Pyrah, I. C., Russell, D. "Finite element modeling of vertical drains beneath embankments on soft ground", Geotechnique, 42(3), pp. 499-511, 1992.

https://doi.org/10.1680/geot.1992.42.3.499

[9] Indraratna, B., Redana, I. W. "Plane-Strain Modeling of Smear Effects Associated with Vertical Drains", Journal of Geotechnical and Geoenvironmental Engineering, 123(5), pp. 474-478, 1997. https://doi.org/10.1061/(ASCE)1090-0241(1997)123:5(474)

[10] Tan, S. A., Tjahyono, S., Oo, K. K. "Simplified Plane-Strain Modeling of Stone-Column Reinforced Ground", Journal of Geotechnical and Geoenvironmental Engineering, 134(2), pp. 185-194, 2008. https://doi.org/10.1061/(ASCE)1090-0241(2008)134:2(185)

[11] Castro, J., Sagaseta, C. "Consolidation and deformation around stone columns: Numerical evaluation of analytical solutions", Computers and Geotechnics, 38(3), pp. 354-362, 2011. https://doi.org/10.1016/j.compgeo.2010.12.006 for consolidation of the subsoil were reached in the case when the stone columns were made of quarry stone. The use of pebble gravel for the stone columns proved to be less effective. Acceptable results from the settlement and consolidation were only obtained in the case of the stone columns installed in a square mesh with dimensions of $1.5 \times 1.5 \mathrm{~m}$. The use of Model 1 led to a determination of a $10-20 \%$ greater settlement and times about twice as long required for consolidation in comparison to Model 2.

[12] Barksdale, R. D., Bachus, R. C. "Design and Construction of Stone Columns, Volume II", School of Civil Engineering, Georgia Institute of Technology, Atlanta, GA, USA, Rep. FHWA/RD-83/027, 1983. [online] Available at: http://www.geotechnicalinfo.com/fhwa_design and_construction_of_stone_columns.pdf [Accessed: 25 June 2019]

[13] Abusharar, S. W., Han, J. "Two-dimensional deep-seated slope stability analysis of embankments over stone column-improved soft clay", Engineering Geology, 120(1-4), pp. 103-110, 2011 https://doi.org/10.1016/j.enggeo.2011.04.002

[14] van Impe, W. F., Debeer, E. "Improvement of settlement behaviour of soft layers by means of stone columns", In: Proceedings of the Eighth European Conference on Soil Mechanics and Foundation Engineering, Helsinki, Finland, 1983, pp. 309-312.

[15] Tran, T. A., Mitachi, T. "Equivalent plane strain modeling of vertical drains in soft ground under embankment combined with vacuum preloading", Computers and Geotechnics, 35(5), pp. 655-672, 2008. https://doi.org/10.1016/j.compgeo.2007.11.006

[16] Weber, T. M. "Modellierung der Baugrundverbesserung mit Schottersäulen (Modeling of ground improvement with stone columns)", Doctoral Thesis, ETH Zurich, 2009. (in German) https://doi.org/10.3929/ethz-a-005462206

[17] Fiala, R., Boštík, J., Kotačková, A., Miča, L., Zdražil, K., Masopust, J. "Štěrkové pilíře - navrhování, provádění a kontrola" (Stone columns technology for practice - design, implementation and control), 1st ed., CERM Academic Publishing House, Brno, Czech Republic, 2014. (in Czech)

[18] Stacho, J. "Analysis of impact of input soil properties in numerical modelling of a stone column", In: Proceedings of the 13th Slovak Geotechnical Conference, Current geotechnical solutions and their verification, Bratislava, Slovakia, 2017, pp. 302-309.

[19] Hayward Baker "Vibro Replacement", [online]. Available at: https:// www.haywardbaker.com/solutions/techniques/vibro-replacement [Accessed: 25 June 2019]

[20] Turcek, P., Sulovska, M., Stacho, J., Ondrasik, M., Frankovska, J., Kopecky, M., Brcek, M., Panuska, J., Suchanekova, E., Rikovska, O. "Experimental research of strength and deformation properties of stone columns", Department of Geotechnics, Slovak University of Technology in Bratislava, Bratislava, Slovakia, Rep. 01/2017, 2017.

[21] Stacho, J., Sulovska, M. "Determination of the density of stone columns using in-situ testing", In: Proceedigns of the 17th International Multidisciplinary Scientific GeoConference SGEM 2017, Albena, Bulgaria, 2017, pp. 223-230. https://doi.org/10.5593/sgem2017/12/S02.029 
[22] Schanz, T., Vermeer, P. A., Bonnier, P. G. "The hardening soil model: Formulation and verification", In: Beyound 2000 in Computational Geotechnics - 10 Years of Plaxis, International symposium, Amsterdam, Netherlands, 1999, pp. 281-296. [online] Available at: https://pdfs.semanticscholar.org/ced1/b3f33e91eeb83951913262611e5a3e85bf6b.pdf [Accessed: 25 June 2019]
[23] Stacho, J., Frankovská, J., Mušec, P. "Numerical Analysis of Stone Columns for Road Embankment Construction", In: Proceedings of China-Europe Conference on Geotechnical Engineering, Vienna, Austria, 2018, pp. 1730-1733.

https://doi.org/10.1007/978-3-319-97115-5_180 